Abstracta Iranica Abstracta Iranica

Revue bibliographique pour le domaine irano-aryen

Volume 23 | 2002

Comptes rendus des publications de $\mathbf{2 0 0 0}$

\title{
Armag்ān-e 'elmī. Lahore, Majles-e Adabiyyāt-e Mašreq, 1998, 584 p. sans les index. [Offrande Scientifique]
}

\section{Arif Naushahi}

\section{(2) OpenEdition}

1 Journals

Édition électronique

URL : http://journals.openedition.org/abstractairanica/35103

DOI : 10.4000/abstractairanica.35103

ISSN : 1961-960X

Éditeur :

CNRS (UMR 7528 Mondes iraniens et indiens), Éditions de l'IFRI

\section{Édition imprimée}

Date de publication : 15 mai 2002

ISSN : 0240-8910

Référence électronique

Arif Naushahi, « Armaġān-e 'elmī. Lahore, Majles-e Adabiyyāt-e Mašreq, 1998, 584 p. sans les index.

[Offrande Scientifique] 》, Abstracta Iranica [En ligne], Volume 23 | 2002, document 11, mis en ligne le 08 février 2010, consulté le 25 septembre 2020. URL : http://journals.openedition.org/abstractairanica/ 35103 ; DOI : https://doi.org/10.4000/abstractairanica.35103

Ce document a été généré automatiquement le 25 septembre 2020.

Tous droits réservés 


\title{
Armaġān-e 'elmī. Lahore, Majles-e Adabiyyāt-e Mašreq, 1998, 584 p. sans les index. [Offrande Scientifique]
}

\author{
Arif Naushahi
}

Recueil d'articles en persan et en ourdou dédiés au professeur Vahīi Qoreyšì (né le 14 février 1925), professeur à l'Université du Penjab, en hommage à ses travaux scientifiques et littéraires. Dans la première partie figurent 44 articles; la deuxième partie contient la biographie de Vahīi Qoreyšĩ et sa bibliographie complète. Un certain nombre d'articles portent sur la littérature persane et sur l'iranologie : Nadīr Ahmad, « Ṣadr ol-Ṣodūr Seyyed Jalāl BoHāāī Raḍavī »; Moḥammad-Reḍā Anșāīi Farangī Maḥallī, «Farḥat ol-Nāẓerīn »; Aḥmad Tafaḍdolīi, « Nām-hā-ye Hูāṣṣ-e īrānī dar Mójam ol-safar » (Les noms propres iraniens dans Mojjam ol-safar) ; Moḥammad Eslam, « Neẓām-e ābresānī va āb-pāšì-ye İrān dar qorūn-e miyāne » (Les systèmes d'irrigation dans l'Iran médiéval); Šarīf Hoseyn Qāsemī, «Gonā Baygom : Šā'ere-ye ordū va fārsī » (Gonā Baygom, poétesse du persan et de l'ourdou); Mo'īn al-Dīn 'Aqīl, « Mo'alef-e Tadkere-ye Negārestān-e SoH̆an» (L'auteur du recueil de biographies Negārestān-e SoHan); “Āref Nowšāhī, «Matnavī-ye Hatț-e Baqdād sorūde-ye Mohammad Māh Ședāqat Konjāhī ». Vahịid Qoreyšì est célèbre en Inde et au Pakistan pour ses recherches en littératures persane et ourdoue ainsi que dans le domaine de l'histoire du sous-continent. Les éditions critiques de Nāme-ye 'ešq, Tavāāqeb ol-manāqeb, Šāhjahān-nāme et de Hamīše bahār comptent parmi ses travaux les plus notoires. 
INDEX

Thèmes : 1.2. Recueils d'articles : revues, colloques, ouvrages collectifs

\section{AUTEURS}

ARIF NAUSHAH

Islamabad - Pakistan 